\title{
Self-efficacy of General English Lecturers after a Home-base Policy Change in an English Department in an Indonesian University
}

\author{
Ahmad Munir \\ Universitas Negeri Surabaya, Indonesia \\ Email Correspondence: ahmadmunir@unesa.ac.id
}

\section{Background:}

Abstract

Teachers' self-efficacy has a role in the success of the teaching and learning process in the classroom. Yet, the self-efficacy of general English lecturers in the context of higher education has rarely been investigated.

\section{Methodology:}

This article reports a study that describes the self-efficacy of former general English lecturers as an implementation of the general English lecturers' home-based policy in the English Department in a university in Surabaya and explains the reasons why they have such self-efficacy. Eight former general English lecturers who had been assigned as skills and contents lecturers in the English department participated in this study. Data were collected through three questionnaires and focused group discussions.

\section{Findings:}

The results of this study indicated that the participants reported high self-efficacy in engaging with students, managing classes, using instructional strategies, using English, and using pedagogical competence, even though there was different self-efficacy, from low to moderate, for some items in the questionnaires. These lecturers reported that they had high self-efficacy in many items in the questionnaires because of students' English competence, the subject matter factor, students' characteristics, and the working environment in the English department.

\section{Conclusion:}

In conclusion, a change in self-efficacy of the general English lecturers occurred along with the teaching experiences of these lecturers in a new teaching context.

Keywords: self-efficacy; general English lecturers; home-based policy.

\begin{tabular}{|c|c|c|}
\hline DOI & : & http//dx.doi.org/10.24903/sj.v5i2.506 \\
\hline Received & : & August 2020 \\
\hline Accepted & : & September 2020 \\
\hline Published & : & October 2020 \\
\hline Copyright Notice & : & $\begin{array}{l}\text { Authors retain copyright and grant the journal right of first publication with the } \\
\text { work simultaneously licensed under a Creative Commons Attribution } \mathbf{4 . 0} \\
\text { International License that allows others to share the work with an acknowledgment of } \\
\text { the work's authorship and initial publication in this journal. } \\
\text { (c) (i) () }\end{array}$ \\
\hline
\end{tabular}

\section{INTRODUCTION}

Self-efficacy has been introduced in social psychology in the 1990s. It is owned by each individual in the social life they live. Schunk and Pajares $(2002,2009)$ defined self-efficacy as "beliefs about one's capability to learn or perform behaviors at designated levels" (p.35). This is similar to personal judgments of the capability to accomplish specific tasks and deal with 
different realities. In a similar vein, Bandura (2006) referred it to a strong self-concept, or a belief, that can encourage individuals to carry out and complete the work they do in society. Self-efficacy is very important in life because it mediates the relationship between knowledge and action (Schunk \& Pajares, 2002) and affects many aspects of life (Bandura, 2010).

Self-efficacy is formed from childhood when one lives their experiences. This may come from mastery experiences, social modeling, social persuasion, and psychological responses (Joët et al., 2011; Pajares, 1996; Schunk \& Pajares, 2002, 2009). Mastery experiences refer to the ability of individuals to solve problems based on personal experience. If one refers to the experience of others, one may not be able to solve the problems one faces in one's way. Social modeling refers to seeing other people solve a problem or reflect on what others will do if they encounter a problem or social conflict as they face it. Social persuasion is an invitation, advice given by the environment or people around to solve social problems being faced by individuals. Psychological responses are feedback that individuals show in the form of emotive responses, empathy for one particular social problem.

These four sources of self-efficacy can also be found in the classroom when one teaches because the classroom can be said to be the smallest social space that resembles a social context outside of school (Phan \& Locke, 2015). Four sources that emerge from the classroom are enactive attainment, vicarious experiences, psychological and emotional states, and verbal and social persuasion (Hastings, 2012; Phan \& Locke, 2015). The four sources that arise from the classroom also emphasize social involvement which is reflected in the self-efficacy that is owned by teachers. Novice teachers and senior teachers have different self-efficacy because the level of experiences tested by the time of the senior teachers and from the novice teachers solving social problems that arise from the classroom need help from all parties involved (Hastings, 2012). Teacher's self-efficacy also relates to the self-efficacy of learners. For example, sports instructors who have low self-efficacy will influence students to be lazy to participate in sports activities that are designed (Breslin et al., 2012).

Teachers' attitudes towards subjects also have an impact on students. For example, mathematics or science instructors who feel that the subjects they are presenting are very difficult; their students will feel the same about the math or science lessons earlier. Conversely, if mathematics or science teachers have a positive attitude towards their subjects, students who take part in their lessons will also feel that mathematics or science lessons are not so torturing (Yara, 2009). Another example, teachers' attitude shown when teaching will build a positive attitude towards the subjects they teach so that students will build conducive situations in the classroom (Ahmad \& Sahak, 2009). If the teacher who teaches in the classroom is too strict in 
teaching the subject or too loose, the students will reflect the attitude that the instructor showed (Lavrič, 2006). In line with this, students will have difficulty with English lessons or students will consider English lessons as easy lessons so that they feel no need to pay attention to the instructor.

In line with the example of sports instructors, the self-efficacy of novice teachers in reading subjects for elementary school students can also influence the success of teaching and learning brought in the classroom (Hastings, 2012). If the novice teacher does not get enough social assistance from the environment in which she teaches, her self-efficacy and teaching methods show poor results. Conversely, if a novice teacher gets enough help from the place where he teaches, help from colleagues such as pieces of advice, he will feel that he can deal with problems that arise when he teaches (Hastings, 2012).

The self-efficacy of the teacher is closely related to the results of self-achievement. Selfefficacy can be owned by students, teachers, and institutions, each of which has a specialization of self-efficacy (Schunk \& Pajares, 2009). A teacher, for example, has self-efficacy on his ability to motivate students and promotes learning will affect the learning environment he wants to create. Also, departments that have collective instructional efficacy will encourage school achievement.

Studies have indicated the roles of self-efficacy for both teachers and students. Research by Caprara et al. (2006), for example, shows that a teacher's self-efficacy becomes a determining factor for the success of students, classrooms, and educational institutions. In Malaysia, Rahman et al. (2010) examined that students' self-efficacy of English language skills has a strong positive relationship with the results of their science learning taught in English. In Venezuela, Chacón's research (2005) shows that English teachers' self-efficacy is positively related to their English skills. The self-efficacy of English teachers in Venezuela studied by Chacón (2005) for the ability of their instructional strategies is higher than their self-efficacy for their management and engagement abilities. In the Iranian context, Eslami and Fatahi (2008) found a strong positive relationship between self-efficacy and the English language skills of English teachers in Iran.

Self-efficacy in teachers' world of work is also an indication of the saturation of working as a teacher. Some studies have indicated this relationship. For example, a study in Germany and Syria on teacher self-efficacy and work stress shows that the stress levels and levels of teaching fatigue that teachers feel are closely related to teachers who rated themselves low (low self-efficacy) (Schwarzer \& Hallum, 2008). Beginner teachers and young teachers are also susceptible to experiencing stress levels and high levels of teaching fatigue (Schwarzer \& 
Hallum, 2008). Likewise, the results of Klassen and Chiu's (2010) research on 1,400 teachers at all levels of education and seniority in the US show that self-efficacy increases and then decreases in mid-career as more and more teaching takes place and when teachers are approaching retirement. The stress level of female teachers is higher than that of male teachers, and elementary teachers have high self-efficacy towards classroom management, while at higher levels teachers have high levels of self-efficacy towards teaching strategies (Klassen \& Chiu, 2010). Klassen and Chiu (2010) research also shows that the higher the stress, the lower the job satisfaction.

A change of teaching context may also contribute to teachers' job satisfaction, and finally, teachers' self-efficacy as Klassen and Chiu (2010) research has indicated previously. This is possible as changing to a new context of teaching or even teaching institutions, and such as a home base policy, may influence teachers' pedagogical success. As found by Ghanizadeh and Moafian (2011) in a language institute in Iran, there is a significant relationship between teachers' self-efficacy and pedagogical success.

However, the self-efficacy of English lecturers in the context of Indonesian higher education has rarely been investigated. In the context of work at a university in Surabaya, 12 lecturers were appointed explicitly as lecturers of general English courses in all faculties since 2005. These lecturers were not home-based in the faculty of languages and arts. In 2012, in line with changes in the then Ministry of National Education's regulations on lecturer linearity, the lecturers were home-based in the faculty of languages and arts, specifically the English Department. The transfer has implications for the obligation to teach special subjects in the English Department, i.e., a change in teaching load from general to specific. This change also made them stressed due to changes in this burden. By the results of previous studies above (Caprara et al., 2006; Chacón, 2005; Klassen \& Chiu, 2010; Schwarzer \& Hallum, 2008), these lecturers are very likely to experience changes in self-efficacy and job satisfaction, which will impact on their workability which in turn will have an impact on the achievements of the students they teach. Therefore, a study on the self-efficacy of general English lecturers who have moved to specific English language education, English Department, the context has been conducted. This study aimed to find out teacher's self-efficacy for teaching in the English Department and to explain the reasons why they had such self-efficacy.

\section{METHODOLOGY}

This study is interpretative, which reveals the internal experience of research subjects (Ary et al., 2010). The experience was the change of teaching context and what is taught by former 
general English lecturers in the English Department in a university in Surabaya. The experiences of these lecturers were expected to be able to reflect their self-efficacy towards their work as English lecturers. The participants of this study were eight lecturers of the English Department who had been lecturers of general English in different faculties at university, namely WWE, ARR, HHN, SVA, NCH, ANL, ZAN, and RWL. They had been teaching skills and content courses in the English Department for three years. Examples of subjects they taught are Critical Listening (by WWE), Business Correspondence (by ARR), Integrated English (Spoken) (by HHN), Intermediate Grammar (by SVA), Translation (by NCH), Introduction to linguistics (by ANL), paragraph writing (by ZAN), Speaking for discussion (by RWL).

This study used two ways for data collection, namely three questionnaires and focused group discussions (FGD). Questionnaire 1 is about general English lecturers' belief about selfefficacy for engaging with students (4 items), managing class (4 items), using instructional strategies (4 items), totaling 12 items. Questionnaire 2 is about beliefs about English competence consisting of 12 items, and Questionnaire 3 consisting of 10 items is about general English lecturers' belief about pedagogical competence (See Appendices 1, 2, 3 for the Questionnaires). These questionnaires use a Likert scale 1-5 with 1- SD: Strongly Disagree; 2- D: Disagree; 3- DK: Don't Know; 4- A: Agree; 5- SA: Strongly Agree. They were adopted from the Questionnaire used in Eslami and Fatahi's (Eslami \& Fatahi, 2008). The adoption was deemed possible as the participants of this study were former general English lecturers.

The results of the Questionnaire were confirmed in a focused group discussion where exploration of their self-efficacy to teach content courses in the English Department was made. The FGD was conducted in 90 minutes of video recording. The FGD questions were made based on the results of the data analysis of Questionnaire 1, Questionnaire 2, and Questionnaire 3. The FGD questions include, but are not limited to, whether they could give a concrete example of what they had answered for the items in the questionnaires and the reasons why they perceived their competence in teaching content subjects in the English Department.

To answer the problems studied, a combination of descriptive statistics and interpretative methods was used. This is because the data collected from self-efficacy questionnaires were presented in Modes, Minimum and Maximum, while FGD data were analyzed qualitatively. Analysis of the results of this Questionnaire was by using Modes, Minimum and Maximum for each of the Questionnaires 1, 2, 3 items. Modes would indicate very high self-efficacy (Mode 5), high self-efficacy (Mode 4), moderate self-efficacy (Mode 3), low self-efficacy (Mode 2), very low self-efficacy (Mode 1). 
The analysis of the results of the focused group discussion was carried out after transcribing the discussion video using simple transcription (Richards, 2003). Video transcription is done so that statements of the participants could be analyzed easily. The results of this qualitative data analysis were interpretations of the experience of former general English lecturers in the English Department. This interpretation is presented in this article.

\section{FINDINGS}

This section presents two subsections to answer two research questions of this study.

\subsection{The self-efficacy of former general English lecturers}

The self-efficacy of former general English lecturers in this study were obtained from questionnaires. The results of descriptive statistics for the questionnaires can be seen in Table 1, Table 2, and Table 3, respectively.

Table 1. Descriptive Statistics of Questionnaire 1

\begin{tabular}{lrrrrrrrrrrrrrc}
\hline & Items & 1 & 2 & 3 & 4 & 5 & 6 & 7 & 8 & 9 & 10 & 11 & 12 \\
\hline $\mathrm{N} \quad$ Valid & & 8 & 8 & 8 & 8 & 8 & 8 & 8 & 8 & 8 & 8 & 7 & 8 \\
\multicolumn{1}{l}{ Mode } & & 0 & 0 & 0 & 0 & 0 & 0 & 0 & 0 & 0 & 0 & 1 & 0 \\
Minsing & & 4 & 4 & 4 & 4 & 4 & 4 & 4 & 4 & 4 & 4 & 4 & 4 \\
Maximum & 3 & 4 & 4 & 3 & 4 & 4 & 4 & 3 & 3 & 4 & 3 & 3 \\
\hline
\end{tabular}

Table 1, the results of Questionnaire 1 (belief about self-efficacy), shows that the mode of the answers to questionnaire items no. 1 to 12 is 4 (Agree). This means that the lecturers participating in this study reported that they had high self-efficacy for engaging students, managing class, and using instructional strategies. To engage with students, they had high selfefficacy such as to: (1) motivate students who show low interest in learning English, (2) make the English class enjoyable for all students, (3) make students believe that they can do well in English (4) make students appreciate the potential benefits associated with learning English.

Besides, they also reported that they had high self-efficacy for class management. In other words, they had high self-efficacy to (5) maintain high students' attendance in my English class, (6) get students to turn in assignments or papers promptly (7) calm down a student who is noisy or uncooperative in their English class (8) establish a classroom management system with each group of students well.

The participants also had high self-efficacy for using instructional strategies. They reported that they had high self-efficacy to (9) use a variety of assessment strategies in their English class (10) provide an alternative explanation or example when their students got confused (11) craft good questions for their students and (12) implement alternative instructional strategies well when a certain strategy did not work. 
However, some individual lecturers reported that they Don't Know (scale 3) for items: 1, $3,4,5,8,9,11,12$ (one for each). This means she or he might not be sure about her or his ability to deal with students, managing class, and implementing learning strategies. In other words, she or he reported having moderate self-efficacy for doing these eight tasks in the items. One participant who answered Don't Know for five questionnaire items (no. 1, 8, 9, 11, 12) is SVA. Another participant, RWL, answered four questions (item no. 3, 5, 8, and 15) with Don't Know. Other participants, ANL and ARR answered two questionnaire items (no. 4, and 9), and one item no. 9 with Don't Know respectively. This suggests that there were individual participants who had different self-efficacy for engaging students, managing class, and using instructional strategies.

The lecturers' self-efficacy in using English was obtained from Questionnaire 2. The results of the analysis of Questionnaire 2 are presented in Table 2.

Table 2. Descriptive Statistics of Questionnaire 2

\begin{tabular}{|c|c|c|c|c|c|c|c|c|c|c|c|c|c|c|}
\hline & & Items & 1 & 2 & 3 & 4 & 5 & 6 & 7 & 8 & 9 & 10 & 11 & 12 \\
\hline \multirow{2}{*}{$\mathrm{N}$} & Valid & & 8 & 8 & 8 & 8 & 8 & 8 & 8 & 8 & 8 & 8 & 8 & 8 \\
\hline & Missing & & 0 & 0 & 0 & 0 & 0 & 0 & 0 & 0 & 0 & 0 & 0 & 0 \\
\hline \multicolumn{2}{|c|}{ Mode } & & 4 & 4 & 4 & 4 & 4 & 5 & 4 & $4^{\mathrm{a}}$ & 4 & 4 & 4 & 4 \\
\hline \multicolumn{2}{|c|}{ Minimum } & & 4 & 3 & 4 & 3 & 2 & 4 & 4 & 4 & 3 & 2 & 4 & 4 \\
\hline \multicolumn{2}{|c|}{ Maximum } & & 5 & 5 & 5 & 5 & 4 & 5 & 5 & 5 & 5 & 5 & 5 & 5 \\
\hline
\end{tabular}

a. Multiple modes exist. The smallest value is shown

As seen in Table 2, the results of Questionnaire 2 about beliefs about English competence show that the mode is 4 (Agree), except for items 6 and 8 (mode 5). This indicates that the participants in this study reported that they had high self-efficacy in using English for: (1) participating in a conversation at normal speed with native English speakers, (2) maintaining a conversation with an English speaker by using strategies, (3) using English as the language of instruction in my English class, (4) watching English news (for example, CNN) and / or English films without subtitles, (5) understanding the meaning of common idiomatic expressions used by English speakers, (6) understanding when two native English speakers talk at a normal speed, (7) understanding English magazines, newspapers, and popular novels, (9) figuring out the meaning of unknown words in English from context, (10) writing business and personal letters in English and always find the right words to convey what they want to say, (11) filling in different kinds of applications forms in English such as a bank account application, and (12) writing a short essay in English on a topic of their knowledge. Special for item no 8, there are multiple modes, 4 and 5. In other words, the participants had very high self-efficacy for using English for (8) drawing inferences/conclusions from what they read in English. 
In addition, the participants had very high self-efficacy for items no. 6 of Questionnaire 2, as the mode is 5 (Strongly Agree). This means that the participants had very high self-efficacy in using English for: (6). understanding when two native English speakers talk at a normal speed, and (8) drawing inferences/ conclusions from what they read in English. The lecturers who had very high self-efficacy for this are NCH, WWE, ZAN, ANL, and RWL.

Despite the high and very high self-efficacy findings above, some participants answered Disagree (scale 2) and Don't Know (scale 3) for questionnaire items no. 5, 9, and 10. This means that some participants had moderate and low self-efficacy in using English for (5) understanding the meaning of common idiomatic expressions used by English speakers, (9) figuring out the meaning of unknown words in English from context, (10) writing business and personal letters in English and always find the right words to convey what they want to say. The participants who had low to moderate self-efficacy in using English for performance in items 5, 9, and 10 include ARR and ANL. ARR reported she was not sure about her abilities in items 5 and 9, namely understanding idiomatic expressions and figuring out the meanings of unknown words in context. Furthermore, there were 2 participants (HHN and SVA) who answered Disagree for items 5 and 3 (using English as a medium of instruction). Two participants, SVA and ARR, reappeared as lecturers who had different trends from other participants.

The results of the analysis of Questionnaire 3 are presented in Table 3.

Table 3. Descriptive Statistics of Questionnaire 3

\begin{tabular}{|c|c|c|c|c|c|c|c|c|c|c|c|c|}
\hline & & Items & 1 & 2 & 3 & 4 & 5 & 6 & 7 & 8 & 9 & 10 \\
\hline \multirow{2}{*}{$\mathrm{N}$} & Valid & & 8 & 7 & 8 & 8 & 8 & 8 & 8 & 8 & 8 & 8 \\
\hline & Missing & & 0 & 1 & 0 & 0 & 0 & 0 & 0 & 0 & 0 & 0 \\
\hline \multicolumn{2}{|c|}{ Mode } & & 2 & $1^{\mathrm{a}}$ & 2 & $4^{\mathrm{a}}$ & $4^{a}$ & 4 & 4 & 2 & 4 & $3^{\mathrm{a}}$ \\
\hline \multicolumn{2}{|c|}{ Minimum } & & 2 & 1 & 1 & 4 & 2 & 4 & 2 & 2 & 3 & 3 \\
\hline \multicolumn{2}{|c|}{ Maximum } & & 5 & 4 & 3 & 4 & 5 & 5 & 5 & 5 & 5 & 5 \\
\hline
\end{tabular}

a. Multiple modes exist. The smallest value is shown

Different from the results of Questionnaire 1 and Questionnaire 2, as seen in Table 3, the results of Questionnaire 3 (belief in pedagogical competence) indicate that there are various modes for different questionnaire items, namely 4 (Agree), 2 (Disagree), 3 (Don't Know), and 1 (Strongly Disagree) respectively. Mode 4 (Agree) is the most for five items (item no 4, 5, 6, 7, and 9). This indicates that participants had high self-efficacy for (4) allowing students to get into groups and discuss answers to problem-solving activities; (5) playing audiotapes that feature native English speakers' conversation exchanges and asking students to answer questions related to the conversation; (6) using grammatical rules to explain complex English sentences to students; (7) playing English films and videos in class and asking students to 
engage in discussions about the films or videos, and (9) asking students to converse with one another in English and encourage them to find opportunities to speak English outside the classroom.

Mode 2 (Disagree) was the participant's answers for items no. 1, 3, and 8. This indicates that the participants had low self-efficacy in (1) using students' native language rather than English to explain terms or concepts that are difficult to understand; (3) asking students to translate single sentences in the English text into their native language; (8) paying more attention to whether students can produce grammatically correct sentences than whether they can speak English with fluency. While these questionnaire items represent some features of the grammar-translation method, the participants were not in favor of them. These items are indeed English learning techniques that are considered non-communicative, namely: using first language (item 1), Translation to first language (item 3), and grammar correctness priority (item 8). The results of Strongly Disagree and Disagree in Questioner 3 show good English competence of the participants.

The participants answered Don't Know (scale 3) for questionnaire item no 10. This means that they had moderate self-efficacy in presenting real-life situations and asking the students in English using appropriate strategies, grammar, communication. Some of the participants' answers to Questionnaire 3 also indicate mode 1 (Strongly Disagree) for item no. 2. That means some of them had low self-efficacy to: ask students to memorize new vocabulary or phrases without showing them how to use the words in context. This is also a non-communicative way of teaching vocabulary so that the participants had low self-efficacy.

\subsection{Why the lecturers had high self-efficacy in engaging with students, managing class, using instructional strategies, using English and pedagogical competence}

The results of the questionnaire analysis above indicate that the participants had high selfefficacy in many items of the Questionnaire for asking about self-efficacy for engaging with students, managing class, using instructional strategies, using English, and using pedagogical competence. As indicated by the mode of their answers presented in Table 1, Table 2, and Table 3, there was variation in some of the answers to items in the questionnaires. To get the reasons why they had such high, moderate, and low self-efficacy, a focused group discussion was conducted. As previously indicated, eight participants took part in the FGD. When asked about the reasons why the results of Questionnaire 1 indicated that the lecturers Agreed (Mode 4) on the self-efficacy items number 1 to 12 , almost all lecturers stated that the English 
competence background of students might influence their self-efficacy. For example, RWL said,

"the answer to item no 3 that 'I can make students believe that they can do well in English' very much depends on our students' background. I used to teach students of the Faculty of Sport Science almost 95\% of non-English students find it difficult to teach English" (RWL in FGD).

This was also echoed by ANL and SVA who taught at the faculty of sports sciences. The students in that faculty had,

"very low interest in English, so it is very difficult to get students' attention during English language lectures" (SVA).

Similarly, students at the Faculty of Education had low interest in English which finally affected the self-efficacy of ZAN. However, students at the Faculty of Economics were enthusiastic about learning English so that HHN claimed to have high self-efficacy in teaching English in that faculty.

When the participants moved to the English department whose students' English competence is at least moderate, they reported that their self-efficacy increased. One participant, ANL stated,

"I have high self-efficacy for teaching Intensive course students in our English department" (ANL in FGD)

The English competence background of these students also influenced the general English lecturers' self-efficacy when teaching in the English Department as lecturers who taught content subjects.

They felt that their self-efficacy changed when they moved to the English Department. ANL, for example, felt that her self-efficacy when teaching Intensive Course (IC) was high, but when teaching in the senior class (semester four and above) ANL's self-efficacy went down. She felt her self-efficacy fluctuated because it turned out that new students needed to be approached with different techniques. It was learned by ANL when she heard conversations outside the classroom with students who accidentally said that they could not learn anything from ANL learning.

Why they also reported moderate self-efficacy for items in the questionnaires was also due to the change in the subject matter they taught. One participant, WWE, for example, stated that at the beginning of moving to the English Department, there were true doubts about whether she could utilize the language laboratory which was of poor quality. She believed that it would not support the teaching of listening comprehension. But this challenge increased her selfefficacy. The contents course for the English Language Education program often became a 
problem for WWE because suddenly the course was given (for example English Language Teaching Method) without being given enough time to prepare it. However, the assistance from the lecturer for that course was felt to reduce the burden of WWE. She felt the need for an adequate adaptation of time for content subjects because finding the materials was difficult.

Similar to WWE, RWL, ZAN, and NCH felt that moving home-base was a challenge for him. RWL states that Speaking 1-4 courses increased her self-efficacy because she compiled the materials and was acknowledged by other senior lecturers in the English Department to be useful and would be used as the learning materials for the course. One senior lecturer would also ask for Literal Reading Course Materials from RWL. This had made RWL and that senior lecturer to work together to compile his teaching materials. All this has made the third factor for high self-efficacy of former English lecturers, the imperfect working environment in the English department.

ZAN stated that the change of teaching environment from other faculty to the English Department caused him to have to study again. At first, ZAN felt insecure about teaching content courses in the English Department. But over time, ZAN began to be more confident. Another lecturer, HHN, felt that courses in the English Department, such as the Intensive Course, Intermediate Grammar, and Business Correspondence were not a problem for her.

$\mathrm{NCH}$ felt that the English Department made him learn teaching content subjects by doing them. He transformed himself from a Test of English Proficiency lecturer to a lecturer of the English-Indonesian Translation course. The challenge he felt from the previous job assignment as general English lecturer to content course lecturer had made him search for theory and appropriate/suitable materials for the translation course.

Another lecturer, ZAN, felt that the writing course materials were different from one lecturer to another. This situation made him think that the English department lecturers who were in charge of that course were not well prepared. On the other hand, this also increased his self-efficacy for teaching writing in the English department. ZAN said, "they were no better than me in teaching skills". In a similar tone, RWL, was not worried anymore when teaching in the English department.

Similarly, SVN felt that it was time for her to increase her self-efficacy. Sharing course materials with a senior lecturer in the English Department had made her self-efficacy up. However, when she learned that there were subjects either skills and contents with unclear contents or course materials such as English-Indonesian Translation, her self-efficacy decreased. The participants were also worried if the subjects assigned to them would be changed in the subsequent semester. 
Concerning the findings of Questionnaire 3, the participants' belief about using pedagogical competence which were various, from high to low self-efficacy, could also be addressed to different students' characteristics. The characteristics of students in the English department were unique. Students in English Literature Study Program, for example, were hard to accept new lecturers. RWL, for example, felt that students of the English Literature Study Program were trouble makers. For RWL, it was not a matter of her self-efficacy, but the students who had problems. RWL felt that she was not welcomed by students of the English Literature Study Program. In a similar tone, ANL felt that senior students did not appreciate the dress code for coming to class. Yet, the participants felt that many lecturers were not concerned about the dress code. From here, ANL felt she had gained self-efficacy to handle rule-breakers. Almost all former general English lecturers had now reported having high self-efficacy, i.e. become confident lecturers.

\section{DISCUSSION}

The first result of this study is that lecturers had high self-efficacy for student engagement class management and instructional strategies after some time teaching in the English Department even though there were also individual participants who had moderate to low selfefficacy for some items in the Questionnaire. This result is in line with the definition of selfefficacy as individuals' perceived capabilities to perform a certain task (Schunk \& Pajares, 2009). Moreover, the participants' high self-efficacy for student engagement class management and instructional strategies suggests that they are competent English lecturers. They felt worried at the beginning of teaching skills and content subjects in the English department, but along with the time they started to gain confidence. This suggests that their self-efficacy changed as self-efficacy is domain-specific, task-specific, and content-specific (Phan \& Locke, 2015).

The finding that there was low self-efficacy for using certain pedagogy such as using students' first language, using Translation, and emphasizing grammatical correctness reflects the lecturers' good pedagogical competence. They know that these are not communicative and unsupportive for students' language development. Therefore, they did not use them. This may have come from their successful experience for using the target language for teaching English. This suggests that this finding supports the finding of Ghanizadeh and Moafian (2011) study on the relationships between teachers' self-efficacy and pedagogical success.

However, there are indeed individual differences in self-efficacy. This is certainly common because there may be differences in initial abilities as Norris-Holt (2001) has stated that the 
willingness to learn English drives achievement in the field of work. The result of this study that the participants had high self-efficacy in using English in their teaching supports NorrisHolt (2001) findings. This also suggests that teachers' self-efficacy can go up or down. This finding supports Klassen and Chiu (2010) research findings.

The second finding of this study is the reasons why they had such self-efficacy, namely the English competence background of the students, the change of subject matter they taught, the working environment in the English Department, and students' characteristics. Students' English competence background in the faculties and English students' English competence were different and acknowledged by the participants as contributing to their self-efficacy. This finding is in line with the sources of self-efficacy of mastery experience, vicarious experience, verbal persuasion, and emotional states (Phan \& Locke, 2015).

Students' low English competence posed challenges to the lecturers. The lecturers, who could speak English well had to adjust with the students by not using English in full. This shows that the lecturers were very tolerant of students' English ability. This finding is in line with Eslami and Fatahi (2008) research finding in that there is a strong positive relationship between self-efficacy and English language skills, but it is different from what happened in McGroarty's research (1995). Students can attend lectures because there are no high expectations as to what happened in the research of Ahmad and Sahak (2009). As a result of the lecturers' treatment of students' low English competence, students self-efficacy may be high as what happened in Yara (2009) study and suggested by Ahmad and Sahak (2009). This would eventually increase the lecturers' self-efficacy following the results of the study of Klassen and Chiu (2010).

The finding that the English Department lecturers who were not from general English lecturers were also imperfect increased the participants' self-efficacy for teaching contents subjects shows that the participants learned quickly to adapt to the new environment. This is an experience, a vicarious one, that becomes the source of self-efficacy as analyzed by Schunk and Pajares (2009) and Joët et al. (2011). The participants realized that no teachers or lecturers were perfect ones. Everyone would learn to be professional along with their career.

Student attitudes are reflections of lecturer attitudes (Lavrič, 2006). The students' characteristics in the classroom, as described by the participants, match what Hastings (2012) found in her study. The problems in dealing with trouble students and the fatigues for teaching all will affect teachers' self-efficacy (Hastings, 2012). The lecturer's concept about the subject and the lack of teaching experience will cause students to have low self-efficacy (Breslin et al., 2012). 
The existence of lecturers who are confirmed as lecturers who had high self-efficacy and the presence of lecturers who only had low self-efficacy indicates the need for a supportive working environment. The finding of this study that the English Department lecturers who were originally home-based in the department assisted the participants of this study proves that verbal persuasion is an important source for teachers' self-efficacy as found in Phan and Locke (2015) study. The fact that these former general English lecturers are lecturers with less than four years teaching in the English Department shows they also need help as Hastings (2012) predicted in terms of English and pedagogical skills. This is consistent with the results of the research of Caprara et al. (2006), also the results of Chacón (2005) research on English language skills, as well as research results from Eslami and Fatahi (2008). Some lecturers teach many classes and then go down self-efficacy by the results of the study of Schwarzer and Hallum (2008) that boredom at the workplace reduces self-efficacy.

\section{CONCLUSION}

Based on the results and discussion previously, some conclusions can be drawn for research on self-efficacy of general English lecturers who were home-based to the English Department in a university in Surabaya. First, the general English lecturers participating in this study after some time teaching in the English Department reported having high self-efficacy for teaching English Department students. This is a relief as what was initially thought to have been stressful for them to change teaching context turned to be blessings for them as they experienced a new teaching assignment. Second, the self-efficacy of the lecturers participating in this study is not always the same for each of them as self-efficacy may come from different sources. That the lecturers undergo self-efficacy changes positively is an indication of their professional development as English language lecturers. Finally, collegial support in a new working place, such as in this study, the English Department, is powerful to maintain lecturers' self-efficacy.

Based on the conclusions above, there are some suggestions for both former general English lecturers and their institutions, the English Department. The first suggestion for the general English lecturers is that they need to continue learning about being English teacher educators to embrace the current challenges. Secondly, the lecturers in the English Department need to increase collaboration between senior and novice lecturers through the budding lecturer mentoring program so that the new lecturers feel at home. Thirdly, the leadership of the English Department needs to provide psychological reinforcement to the lecturers of the former general English in the process of capturing this lecturer. Finally, for the future researchers need to 
discover whether the original lecturers from the English Department also have high selfefficacy.

\section{REFERENCES}

Ahmad, A., \& Sahak, R. (2009). Teacher-student attachment and teachers'attitudes towards work. Jurnal Pendidik Dan Pendidikan, 24, 55-72.

Ary, D., Jacobs, L. C., Sorensen, C., \& Razavieh, A. (2010). Introduction to research in education. Wadsworth, Cengage Learning.

Bandura, A. (2006). Guide for constructing self-efficacy scales. In Self-efficacy Beliefs of Adolescents (pp. 307-337). Information Age Publishing.

Bandura, A. (2010). Self-efficacy. In The Corsini Encyclopedia of Psychology (pp. 1-3). John Wiley \& Sons, Inc. https://doi.org/10.1002/9780470479216.corpsy0836

Breslin, G., Hanna, D., Lowry, R., McKee, D., McMullan, K., Haughey, T. J., \& Moore, N. (2012). An exploratory study of specialist and generalist teachers: predicting self efficacy in delivering primary physical education. In Working papers in health science (Vol. 1, Issue 1). http://eprints.chi.ac.uk/id/eprint/987/

Caprara, G. V., Barbaranelli, C., Steca, P., \& Malone, P. S. (2006). Teachers' self-efficacy beliefs as determinants of job satisfaction and students' academic achievement: A study at the school level. Journal of School Psychology, 44(6), 473-490.

https://doi.org/10.1016/j.jsp.2006.09.001

Chacón, C. T. (2005). Teachers' perceived efficacy among English as a foreign language teachers in middle schools in Venezuela. Teaching and Teacher Education, 21(3), 257272. https://doi.org/10.1016/j.tate.2005.01.001

Eslami, Z., \& Fatahi, A. (2008). Teachers' sense of self-efficacy, English proficiency, and instructional strategies: A study of nonnative EFL teachers in Iran. TESL-EJ, 11(4), n4. http://www.tesl-ej.org/wordpress/issues/volume11/ej44/ej44a1/

Ghanizadeh, A., \& Moafian, F. (2011). The relationship between Iranian EFL teachers' sense of self-efficacy and their pedagogical success in Language Institutes. Asian EFL Journal, 13(2), 249-272. https://asian-efl-journal.com/PDF/Volume-13-Issue-2Ghanizadeh.pdf

Hastings, P. (2012). Early career teachers' self-efficacy for balanced reading instruction. Australian Journal of Teacher Education, 37(6), 55-72. https://doi.org/10.14221/ajte.2012v37n6.2

Joët, G., Usher, E. L., \& Bressoux, P. (2011). Sources of self-efficacy: An investigation of elementary school students in France. Journal of Educational Psychology, 103(3), 649663. https://doi.org/10.1037/a0024048

Klassen, R. M., \& Chiu, M. M. (2010). Effects on teachers' self-efficacy and job satisfaction: Teacher gender, years of experience, and job stress. Journal of Educational Psychology, 102(3), 741-756. https://doi.org/10.1037/a0019237

Lavrič, A. (2006). Teachers' reflections on their attitude toward students. Proceedings of the 31st Annual ATEE Conference: Co-Operative Partnerships in Teacher Education, 5966. http://www.pef.uni-lj.si/atee/978-961-6637-06-0/059-065.pdf

McGroarty, M. (1995). Language attitudes, motivation, and standards. In Sociolinguistics and Language Teaching (pp. 3-46). Cambridge University Press. https://doi.org/10.1017/CBO9780511551185.004

Norris-Holt, J. (2001). Motivation as a contributing factor in second language acquisition. 
The Internet TESL Journal, 7(6), 1-8.

Pajares, F. (1996). Self-efficacy beliefs in academic settings. Review of Educational Research, 66(4), 543-578. https://doi.org/10.3102/00346543066004543

Phan, N. T. T., \& Locke, T. (2015). Sources of self-efficacy of Vietnamese EFL teachers: A qualitative study. Teaching and Teacher Education, 52, 73-82. https://doi.org/10.1016/j.tate.2015.09.006

Rahman, S., Mazlan, M., Kummin, S., Yasin, R. M., \& Meerah, T. S. M. (2010). Examining the role of language on students achievement: a study on the use of second language as a medium of instruction in teaching science subject in Malaysia. Procedia-Social and Behavioral Sciences, 9, 1261-1265. https://doi.org/10.1016/j.sbspro.2010.12.317

Richards, K. (2003). Qualitative inquiry in TESOL. In Qualitative Inquiry in TESOL. Palgrave Macmillan UK. https://doi.org/10.1057/9780230505056

Schunk, D. H., \& Pajares, F. (2002). The development of academic self-efficacy. In Development of Achievement Motivation (pp. 15-31). Elsevier. https://doi.org/10.1016/B978-012750053-9/50003-6

Schunk, D. H., \& Pajares, F. (2009). Self-efficacy theory. In K. Wentzel \& A. Wigfield (Eds.), Handbook of motivation at school (pp. 35-53). Routledge.

Schwarzer, R., \& Hallum, S. (2008). Perceived teacher self-efficacy as a predictor of job stress and burnout: Mediation analyses. Applied Psychology, 57(s1), 152-171. https://doi.org/10.1111/j.1464-0597.2008.00359.x

Yara, P. O. (2009). Relationship between teachers' attitude and students' academic achievement in mathematics in some selected senior secondary schools in southwstern Nigeria. European Journal of Social Sciences, 11(3), 364-369. 